\title{
Role of Dictatorship in the Good Governance of Pakistan
}

\author{
Dr. Mustafa Hyder \\ Assistant Professor, Department of Public Administration, University of Karachi \\ Dr. Syed Shahid Zaheer Zaidi \\ Assistant Professor, Department of Public Administration, University of Karachi
}

\begin{abstract}
"Government by the people, of the people, for the people" is a famous quote by Abraham Lincoln. But in Pakistan, the phrase "for the people" has a very rare existence because the politicians want to gain the maximum power rather than to work for the common masses or for the welfare of the state. Both of the two major forms of government have been practiced in Pakistan and we have experienced the repercussions of them respectively. In Pakistan dictatorship seems rightful to the fact that our country has a low literacy rate which causes hindrances for the people in the way to choose the right political party who will govern effectively for the state. And most importantly throughout the tenure of dictatorship in Pakistan, we have observed that the economy was stabilized and went to the recession which raises the question that 'Is dictatorship more beneficial for Pakistan's economy or not?' Many comparative analysis studies of democracy and dictatorship have been conducted but still, the issue has not been solved that which type of government is best for Pakistan. Therefore the purpose of this research is to gather the facts and information from the common masses especially (the youth) about the dictatorship era and what role it has played in the development, economic stabilization and in the good governance of Pakistan which will help us in getting our anticipated result that whether dictatorship is suitable for Pakistan or not.The expected results and findings of our research would be indicating that either dictatorship is suitable for good governance of Pakistan or Dictatorship is not suitable for good governance of Pakistan. The second anticipated findings of data analysis might be results in approving that the major development took place in the dictatorship era or the major development did not take place in the dictatorship era.
\end{abstract}

Keywords: Forms of Government in Pakistan, Dictatorship, Economic Growth and Dictatorship

DOI: $10.7176 / \mathrm{JESD} / 10-8-18$

Publication date: April $30^{\text {th }} 2019$

\section{Introduction}

In the huge time span of 71 years of Pakistan's independence, there has seen three different military dictatorships along with four democracies but still the debate of which is best for Pakistan; Democracy or either Dictatorship is still not coming to an end. The people of Pakistan have experienced the different implications of dictatorships. That is why there is a need of such kind of research which highlights the performance of dictators in different cadres in Pakistan to better analyze and interpret the growth and development as well as the short comings of aroused in their tenures. In a dictatorship, power is given too much to one person that he may or even sometimes do misuse the power and the authority in his own ways which at times are not in the prosperity of the country consequently the dictator starts to lose the legitimacy of the government. In this research paper we will discuss the opinions and thoughts of the people that what they perceive and think about the accomplishments and the drawbacks of the dictators in various areas such as health and education, judicial review, developmental welfare projects, management and administration of the institutions, rank in the international market, rule of law and exercise of justice. The readers have also asked such type of questions in which they can share and express their views on whether dictatorship is suitable for Pakistan, has it played a good role in uplifting the economy of Pakistan and the level of good governance the dictators have achieved in their tenures.

\section{Literature Review}

A dictatorship is an absolute form of government, featured by a single leader or group of leaders who clench all political powers (Gürsoy, 2017) . And takes control of a political situation, family, a classroom or even a campaign exploration. Three different types of dictatorship are autocracy, authoritarian oligarchy, and absolute (Gitz, 1992). In an autocracy, absolute political power is hold by one person. The older and more traditional form of autocracy is an absolute monarchy. A person who holds unlimited political power is a hereditary monarch (king or queen, emperor or empress), the governmental system is an absolute monarchy. Authoritarian oligarchy, or collective dictatorship, is featured by absolute rule of the few. Unchecked, supreme political power remains in the hands of a very small number of persons who make up single cohesive elite. One particular type of authoritarian oligarchy in the modern world is the one-party state (Tullock, 1987). The one-party state has been the typical pattern of government in Communist-ruled societies. As a political regime can be constitutional without being democratic, one can be democratic without being constitutional. A government that is democratic, but not constitutional, is 
called an absolute democracy. Absolute democracy, or majoritarian dictatorship, is featured by absolute, or unlimited, rule of the majority. Unchecked, supreme political power is in the hands of a simple majority of the adult citizens or their democratically elected representatives (Aragonès, 2009).

In 1958 and there have been three successful attempts. There have also been numerous unsuccessful attempts since 1951. Since its creation in 1947, Pakistan has spent several decades under military rule (1958 -1969, 19691971, 1977- 1988, 1999 - 2008) (Bano, 2012). The first time military was directly involved in politics of the country was when General Ayub Khan seized power through a bloodless coup in October 1958. Ayub Khan's era is remembered for successful industrialization and rural development through constructing modern national freeways. Various energy conservation programs were accomplished like Mangla Dam and few small dams and water reservoirs. Education reforms took place on large scale along with the efforts of scientific development. Many public sector schools and universities were built in his era (Gill \& Pugatch, 2005).

On March 25, 1969, Gen. Ayub Khan resigned and handed over the power to the Commander-in-Chief of Pakistan Army, General Muhammad Yahya Khan, who imposed martial law straight away (Ziring, 2009) . Yahya Khan in his regime needed to deal with the tremendous hassles and was forced to perform the multiple roles of caretaker head of the country, drafter of a provisional constitution, resolving the One Unit question, satisfying the frustrations and the sense of exploitation and discrimination successively created in the East Pakistan by a series of government policies since 1948. After the partition of East Pakistan, Yahya expeditiously surrendered his powers to Zulfikar Ali Bhutto, on December 20, 1971 (Burki, 1980).

In 1977, General Zia Ul Haq dissolved the National Assembly of Pakistan and all provincial assemblies and suspended the constitution of Pakistan as well. The martial law enforced by President General Zia introduced the strict but modern form of conservatism which promoted the nationalistic and religious programmes.

On 15 October 1999, General Parvez Musharraf declared a state of emergency, suspended the Constitution, and assumed power as Chief Executive of Pakistan. He worked on women empowerment at all tiers of government and legislation against honour killings. Media was given empowerment by giving total freedom to press and print media and flow of information. Wide ranging economic reforms took place in his regime and there was development in science and technology, education and health sectors. Emphasized on human resource development. Musharraf was the first military president to accept the rulings of the Supreme Court and holding free and fair elections in 2002 in his vision to return the democracy in the country and called for nationwide political elections (Khan, 2011). General Pervez Musharraf introduced the Local Government System in order to establish democracy at grassroots level. This was not a new experiment in Pakistan, Ayub Khan had taken up a similar effort in this direction by introducing the Basic Democracy System.

Democracy is that form of government in which sovereignty remains in the hands of the entire nation, which can make and break the government. There are two types of democracy, Direct Democracy, and Indirect democracy/representative democracy. In a directdemocracy, the people participate directly in the affairs of the state (Bhat, 2011). The people themselves are the rulers and they are the ruled at the same time. They themselves make the laws, enforce them and decide cases according to these laws. For indirect democracy, the states having the population in larger number, it became impossible for all the people directly to participate in the affairs of the country. Under this form of government, people elect a small number of representatives or delegation and give them the authority to run the government. Today in almost all the countries of the world there is an indirect or representative democracy (Kapur, 1997) .

Democracy is one of the ideologies and systems upon which Pakistan was sought to be established in 1947 as a nation-state, as envisioned by the leader and founder of the nation, Muhammad Ali Jinnah. Pakistan constitutionally is a democratic parliamentary republic with its political system based on an elected form of governance. However, in past history, because of the military coups and political uncertainty, there have been fluctuations in the democracy. Since 2008. now Pakistan is one of the newest functioning democracies, with the first democratic elections held in 2013 to complete a 5-year term for the first time in its political history. As of current status, Pakistan is also the 5th largest and is also the largest Majoritarian democracy and (non-liberal) in the world and perhaps considered as the world's largest Islamic democracy within the Muslim world.

\section{Objective of the Study}

The goal of our research is to know about what role dictatorship played in Pakistan and to know either this system suits Pakistan or not. The overall purpose of the research is to obtain answers to research questions and to validate the hypothesis.

\section{Hypothesis}

The purpose of research is to gauge that according to the students of Karachi University, either the dictatorship plays an adequate role in the good governance of Pakistan or not. The data was collected on the basis of below statements.

Ho: Dictatorship is suitable for good governance of Pakistan. 
HA: Dictatorship is not suitable for good governance of Pakistan.

Ho: Major developments took place in the dictatorship era.

HA: Major developments did not take place in the dictatorship era.

\section{Variables}

Dictatorship is the independent variable as they operate in their own way, whereas good governance is the dependent variable, which depends upon the operation of the dictatorship. And according to in the second hypothesis, dictatorship era is the independent variable and major developments are the dependent variable.

\section{Methodology}

We have conducted a descriptive study through which we have described the different factors, events and situations occurring while having a dictatorship in Pakistan. The research would be quantitative as well as qualitative in nature whereas the results of the research are based on the quantitative data which have collected from getting views from the masses (especially the youth). We have chosen the survey research strategy in which questionnaires are being employed as our survey instrument. Since our research is descriptive or explanatory in nature so we could efficiently collect the data by using the mechanism of survey research in which we personally administered the questionnaires to the respondents. We have chosen the close-ended questionnaire type because it helped us to code the information easily for subsequent analysis. Since our questionnaire is a mixture of quantitative and qualitative research therefore Likert scale, Nominal scale and Ordinal scale are exercised as per the need that was required by the variables of the research. We have employed the probability sampling design which is more commonly known as Simple Random Sampling and in non-probabilistic sampling design, we have applied the simple random and convenience sampling.

The quantitative research was conducted by getting the samples from our targeted population i.e. 500 students of Karachi University. Responses of the students had taken through the close-ended questionnaire.

\section{Data Analysis}

\begin{tabular}{|c|c|c|c|c|c|}
\hline & & \multicolumn{2}{|c|}{ Yes } & No & $\begin{array}{l}\text { Don't } \\
\text { Know }\end{array}$ \\
\hline \multicolumn{2}{|l|}{ 1. Is dictatorship better for Pakistan? } & \multicolumn{2}{|c|}{$34 \%$} & $46 \%$ & $20 \%$ \\
\hline \multicolumn{2}{|c|}{$\begin{array}{l}\text { Is dictatorship really a replacement of democratic } \\
\text { government in an uncertain emergency condition? }\end{array}$} & \multicolumn{2}{|c|}{$46 \%$} & $36 \%$ & $18 \%$ \\
\hline \multicolumn{2}{|c|}{ Do you think dictatorship reduce corruption? } & \multicolumn{2}{|c|}{$52 \%$} & $38 \%$ & $10 \%$ \\
\hline \multicolumn{2}{|l|}{ Is dictatorship impose better rule of law? } & \multicolumn{2}{|c|}{$58 \%$} & $30 \%$ & $12 \%$ \\
\hline \multicolumn{2}{|c|}{$\begin{array}{l}\text { Do you think military rule highly contributed in } \\
\text { education and health care sectors in Pakistan? }\end{array}$} & \multicolumn{2}{|c|}{$46.9 \%$} & $22.4 \%$ & $30.7 \%$ \\
\hline \multicolumn{2}{|c|}{$\begin{array}{l}\text { 6. What do you think has judicial review been given } \\
\text { more to people in dictatorship rule? }\end{array}$} & \multicolumn{2}{|c|}{$27.1 \%$} & $27.1 \%$ & $45.8 \%$ \\
\hline & $\begin{array}{l}\text { Strongly } \\
\text { Agree }\end{array}$ & Agree & Neutral & Disagree & $\begin{array}{l}\text { Strongly } \\
\text { Disagree }\end{array}$ \\
\hline $\begin{array}{l}\text { 7. Dictatorship is best for the good } \\
\text { governance. }\end{array}$ & $10 \%$ & $30 \%$ & $36 \%$ & $12 \%$ & $12 \%$ \\
\hline $\begin{array}{l}\text { Dictators are more towards the } \\
\text { development of welfare projects than } \\
\text { democracy. }\end{array}$ & $6 \%$ & $32 \%$ & $24 \%$ & $36 \%$ & $2 \%$ \\
\hline $\begin{array}{l}\text { 9. Dictators regime is more organized } \\
\text { and managed efficiently versus } \\
\text { democracy. }\end{array}$ & $10 \%$ & $40 \%$ & $32 \%$ & $12 \%$ & $6 \%$ \\
\hline $\begin{array}{l}\text { 10. Dictator's regime is more credible for } \\
\text { international market. }\end{array}$ & $2.2 \%$ & $22.4 \%$ & $36.7 \%$ & $26.5 \%$ & $12.2 \%$ \\
\hline \multirow[t]{2}{*}{$\begin{array}{l}\text { 11. If Pakistan has } 30 \text { years of continuous } \\
\text { military rule without several lost } \\
\text { decades, its economy would have } \\
\text { been several times larger than it is } \\
\text { today. }\end{array}$} & $16 \%$ & $26 \%$ & $34 \%$ & $14 \%$ & $10 \%$ \\
\hline & Dictatorship & \multicolumn{2}{|c|}{ Democracy } & $\begin{array}{l}\text { Khalifa } \\
\text { System }\end{array}$ & Other \\
\hline $\begin{array}{l}\text { 12. Which form of government suits in } \\
\text { Pakistan? }\end{array}$ & $22 \%$ & \multicolumn{2}{|c|}{$40 \%$} & $30 \%$ & $8 \%$ \\
\hline
\end{tabular}




\begin{tabular}{|c|c|c|c|}
\hline & Dictatorship & Democracy & None \\
\hline $\begin{array}{l}\text { 13. Which government has given more } \\
\text { justice to people? }\end{array}$ & $30 \%$ & $28 \%$ & $42 \%$ \\
\hline \multicolumn{4}{|c|}{ 14. What is the major reason that democracy fails to prevail in Pakistan? } \\
\hline Lack of education & \multicolumn{3}{|c|}{$26 \%$} \\
\hline Lack of political will by leaders & \multicolumn{3}{|c|}{$40 \%$} \\
\hline Cast system in the political structure & \multicolumn{3}{|c|}{$24 \%$} \\
\hline Financial crisis & \multicolumn{3}{|c|}{$4 \%$} \\
\hline other & \multicolumn{3}{|c|}{$6 \%$} \\
\hline \multicolumn{4}{|c|}{ 15. Which era of dictatorship has served best in Pakistan? } \\
\hline Ayub Khan's & \multicolumn{3}{|c|}{$34 \%$} \\
\hline Yahya Khan's & \multicolumn{3}{|c|}{$4 \%$} \\
\hline Zia Ul Haq's & \multicolumn{3}{|c|}{$14 \%$} \\
\hline Parvez Musharraf's & \multicolumn{3}{|c|}{$38 \%$} \\
\hline None of them & \multicolumn{3}{|c|}{$10 \% \mathrm{~s}$} \\
\hline
\end{tabular}

\section{Discussion}

Out of 50 students, $46 \%$ says that dictatorship is not better for Pakistan and $46 \%$ says that dictatorship is really a replacement of democratic government in an uncertain emergency condition. It indicates that however dictatorship is the alternate in the emergency conditions in the state but it is not for the permanent solution or it is not the better way for Pakistan.

More than $50 \%$ of the students think that dictatorship reduce the corruption and impose better rule of law and $46.9 \%$ think military rule highly contributed in education and health care sectors of Pakistan. In these questions, $10-22 \%$ students don't know the answers, seems like they are not much aware of dictator's eras. $27.1 \%$ of students agree and disagree equally that the judicial review has been given to people in the dictatorship era whereas $45.8 \%$ don't know about it. The results show that although many students are not aware of the past circumstances, however, many students agree that the development took place in the dictatorship era.

About $40 \%$ thinks dictatorship best for good governance whereas 24\% don't. 38\% think dictators are more towards the development of welfare projects than democracy whereas $38 \%$ don't. $50 \%$ of students think dictator's regime more organized and managed efficiently versus democracy and $24.6 \%$ agree that the regime is more credible in the international market whereas 39\% disagree. $42 \%$ of students agree that if Pakistan has 30 years of continuous military rule without several lost decades, its economy would be several times larger than it is today, whereas $24 \%$ disagree this. In these questions, $32-36 \%$ students gave neutral responses.

$40 \%$ of students think the democratic form of government suits in Pakistan, whereas 22\% supports dictatorship and 30\% support for the Khalifa system. $28 \%$ of students think in democracy more justice has been given to people, whereas 30\% think about that in a dictatorship and 38\% students go against them both. Majority of the students think that democracy fails in Pakistan mainly due to lack of political will by leaders. $38 \%$ and $34 \%$ of the students think that General Ayub Khan's and General Parvez Musharraf's dictatorship era simultaneously served best in Pakistan.

Seeing the responses of the students, it is spotted that according to them dictators played well in the good governance of Pakistan but when we ask about which system suits Pakistan, the majority of them go for the democracy. This might be because of the features that democracy offers i.e. freedom of speech, right to vote and other reasons. However, dictatorship contributed in the good governance but still, the priority to governing will be given to the democracy.

\section{Conclusion}

Overall, it may be said that majority of the people are of the view that in an uncertain emergency condition dictatorship can be a replacement of democracy and they also agree that dictatorship is best for good governance but when it comes to the question that which form of government is suitable in Pakistan so they prefer and go with democracy to prevail in Pakistan.

The common masses agree that even though in the disciplines of rule of law, education and healthcare sectors, justice, development welfare projects, and eradication of corruption; dictators have made huge contributions but their initial ideology is to have democratic system in Pakistan in which freedom of expression and speech is exercised and all the citizens have an equal right to participate by voting to their favourite political party. Therefore our society needs such a type of democratic government which does not misuse power and do not accommodate money to fulfill its own desires but rather it should work for the welfare of the country.

A system in which supremacy of the constitution should prevails. Besides all the interpretation and analysis, masses should also do their best and contribute to the fullest at their stance in order to flourish the economy of the 
country. As a good citizen, everyone should fulfill his/her own job with full honesty and loyalty instead of just blaming the government all the time because it is a two way process between the masses and the government of achieving harmony and prosperity in the country.

\section{Recommendation}

After doing the analysis and interpretation of the results and findings which we have gathered throughout our research by different means which includes both primary as well as secondary data, we have now come to the point that there must be a corruption free democratic government. Since corruption is the problem we have faced in every cadre of the government so it is necessary to eradicate it first by employing a strong accountability mechanism at all the levels in the institutions and in the departments of the government.

After doing the analysis of the results, we have found that people embrace dictatorship because of the fact that in a military rule, they have experienced and observed a very organized and well managed set up which indicates proper organizing, timely planning, adequate staffing and exact controls that are required at all the levels of government. Therefore our democratic government should meet the expectations of the people and must address the issues and difficulties which the common masses are facing.

The government should also incorporate modern communication mechanisms to ensure satisfactory and consistent networking and coordination among all the departments from top to bottom.

Steps and measures should be taken to improvise the hierarchical chain of command which is less time consuming. Skilled and educated professionals should be hired on merit basis in order to ensure efficient and effective working in all the dimensions of the government so that information is processed in a more organized way just like in a dictatorship.

The democratic government must be aware of the needs and problems of the common masses and there must be such a system which helps in enabling all the citizens to easily have an approach to the government officials to inform their necessities and explain about the issues they have been suffering from. Later on, steps should be taken to uplift the economic stability and developmental welfare projects in order to provide a better standard of living to all the citizens of the country.

\section{References}

Acemoglu, D., \& Robinson, J. A. (2006). Economic origins of dictatorship and democracy. Cambridge; Cambridge University Press. Retrieved from http://www.loc.gov/catdir/toc/ecip0511/2005011262.html

Aragonès, E. (2009). The Political Economy of Democracy. Fundacion BBVA.

Arif, B. W., Kayani, F. N., \&Kayani, M. U. N. (2012). The Interrelationship between Democracy and Economic Growth: Theories and Empirics. Pakistan Journal of Social Sciences (PJSS), 32(1), 199-208.

Bano, M. (2012). Breakdown in Pakistan: How Aid Is Eroding Institutions for Collective Action. Stanford University Press.

Bhagwati, J. N. (2002). Democracy and development: Cruel dilemma or symbiotic relationship?.Review of Development Economics, 6(2), 151-162.

Bhat, M. S. (2011). An Introduction to Political Theory - Politics. Educreation Publishing.

Burki, S. J. (1980). Pakistan Under Bhutto: 1971-1977. MacMillan Press.

Gerring, J., Bond, P., Barndt, W. T., \& Moreno, C. (2005). Democracy and economic growth: A historical perspective. World Politics, 57(03), 323-364

Gill, I. S., \& Pugatch, T. (2005). At the Frontlines of Development: Reflections from the World Bank. World Bank Publications.

Gitz, B. R. (1992). Armed Forces and Political Power in Eastern Europe: The Soviet/Communist Control System. Greenwood Press.

Gürsoy, Y. (2017). Between Military Rule and Democracy: Regime Consolidation in Greece, Turkey and Beyond. University of Michigan Press.

Gleditsch, K. S., \& Ward, M. D. (2006). Diffusion and the International Context of Democratization. International Organization, 60(04), 911-933. doi:10.1017/S0020818306060309

Haber, S., \& Menaldo, V. (2011). Do Natural Resources Fuel Authoritarianism? A Reappraisal of the Resource Curse. American Political Science Review, 105(1), 1-26. doi:10.1017/S0003055410000584

Hadenius, A., \& Teorell, J. (2007). Pathways from Authoritarianism. Journal of Democracy, 18(1), 143-157.

Held, D. (2006). Models of Democracy, 3rd Edition. Stanford University Press.

https://nation.com.pk/30-Nov-2018/democracy. (n.d.).

New Haven. Kailitz, S. (2013). Classifying political regimes revisited: legitimation and durability. Democratization, 20(1), 39-60. doi:10.1080/13510347.2013.738861

Kapur, A. C. (1997). Principles of Political Science. Chand Publishing.

Khan, K. A. (2011). 2002 Elections in Pakistan: A Reappraisal. Journal of Political Studies , 18 (1), 93-108.

Khan, S. (2012). The military and economic development in Pakistan.Political Economy Research Institute, 
University of Massachusetts working paper series, 291.

Kaufmann, D., \&Kraay, A. (2002).Growth without governance.World Bank Policy Research Working Paper, (2928).

Kurzman, C., Werum, R., \& Burkhart, R. E. (2002). Democracy's effect on economic growth: a pooled time-series analysis, 1951-1980. Studies in Comparative International Development, 37(1), 3-33.

Nawaz, A. (2013). External Debts: A Comparative Study of Pakistan in Democratic and Military Regimes. Journal of Business Strategies, 7(1).

Olson Jr, M., Sarna, N., \&Swamy, A. V. (2000). Governance and growth: A simple hypothesis explaining crosscountry differences in productivity growth. Public Choice, 102(3-4), 341-364.

Polterovich, V., \& Popov, V. (2007).Democratization, quality of institutions and economic growth.Quality of Institutions and Economic Growth (July 2007).

Rigobon, R., \&Rodrik, D. (2005). Rule of law, democracy, openness, and income. Economics of transition, 13(3), 533-564.

Rivera-Batiz, F. L. (2002). Democracy, governance, and economic growth: theory and evidence. Review of Development Economics, 6(2), 225-247.

Tullock, G. (1987). Autocracy. Springer Science \& Business Media.

Wahman, M. (2013). Opposition Coalitions and Democratization by Election. Government and Opposition, 48(01), 3-32. doi:10.1017/gov.2012.5

Zakaria, F. (1997). The Rise of Illiberal Democracy. Foreign Affairs, 76, 22-43.

Ziring, L. (2009). The Ayub Khan Era: Politics in Pakistan, 1958-1969. Paramount Publishing. 